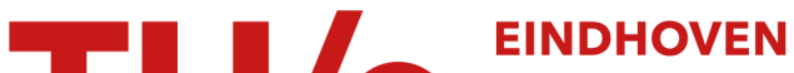 UNIVERSITY OF TECHNOLOGY
}

\section{On numerical problems when reactivity ratios are computed using the integrated copolymer equation}

\section{Citation for published version (APA):}

Hautus, F. L. M., German, A. L., \& Linssen, H. N. (1985). On numerical problems when reactivity ratios are computed using the integrated copolymer equation. Journal of Polymer Science, Polymer Letters Edition, 23(6), 311-315. https://doi.org/10.1002/pol.1985.130230606

DOI:

10.1002/pol.1985.130230606

Document status and date:

Published: 01/01/1985

\section{Document Version:}

Publisher's PDF, also known as Version of Record (includes final page, issue and volume numbers)

\section{Please check the document version of this publication:}

- A submitted manuscript is the version of the article upon submission and before peer-review. There can be important differences between the submitted version and the official published version of record. People interested in the research are advised to contact the author for the final version of the publication, or visit the $\mathrm{DOI}$ to the publisher's website.

- The final author version and the galley proof are versions of the publication after peer review.

- The final published version features the final layout of the paper including the volume, issue and page numbers.

Link to publication

\section{General rights}

Copyright and moral rights for the publications made accessible in the public portal are retained by the authors and/or other copyright owners and it is a condition of accessing publications that users recognise and abide by the legal requirements associated with these rights.

- Users may download and print one copy of any publication from the public portal for the purpose of private study or research.

- You may not further distribute the material or use it for any profit-making activity or commercial gain

- You may freely distribute the URL identifying the publication in the public portal.

If the publication is distributed under the terms of Article 25fa of the Dutch Copyright Act, indicated by the "Taverne" license above, please follow below link for the End User Agreement:

www.tue.nl/taverne

Take down policy

If you believe that this document breaches copyright please contact us at:

openaccess@tue.nl

providing details and we will investigate your claim. 


\title{
On Numerical Problems When Reactivity Ratios Are Computed Using the Integrated Copolymer Equation
}

\author{
F. L. M. HAUTUS and A. L. GERMAN, Laboratory of Polymer Chemistry, \\ Eindhoven, University of Technology, Eindhoven, The Netherlands, and H. N. \\ LINSSEN, * Department of Mathematics, Eindhoven University of Technology, \\ Eindhoven, The Netherlands
}

The copolymer equation introduced in $1944^{1,2}$

$$
\frac{d \mathrm{M}_{1}}{d \mathrm{M}_{2}}=\frac{r_{1} q+1}{r_{2} / q+1}
$$

describes, at any time during the course of a reaction, the exact relationship between the compasition of the momentary monomer feed mixture $\left(q=\mathbf{M}_{1} / \mathbf{M}_{2}\right)$ and the instantaneous copolymer composition $\left(d \mathrm{M}_{1} / d \mathrm{M}_{2}\right)$ formed. A number of methods to determine the reactivity ratios $r_{1}$ and $r_{2}$ are based on eq. (1) using observed feed and copolymer compositions. However, as the degree of conversion increases most copolymerization systems will show a drift in both the monomer feed ratio and the copolymer composition, due to the different reactivities of the radical toward each of the monomers. So model (1) is not exactly valid for nonzero conversion. In some methods this problem is approximately solved by using average feed ratio and copolymer composition or some other approximation..$^{3-6}$ Nevertheless, all methods result in biased values for the reactivity ratios. This bias is not always insignificant.

Integration of eq. (1) gives an exact relationship between conversion (based, for example, on monomer 2 ) and the monomer feed ratio:

$$
G_{2}=\left(\frac{q}{q}\right)^{-1-x_{2}}\left(\frac{q-x_{1} / x_{2}}{q_{0}-x_{1} / x_{2}}\right)^{1+x_{1}+x_{2}}
$$

where $\left(G_{2}=1\right.$ - conversion monomer $2, q_{0}=$ initial $q, x_{1}=1 /\left(r_{1}-1\right)$, and $x_{2}=$ $1 /\left(r_{2}-1\right)$. Equation (2) is valid also for high conversion. From a computational point of view eq. (2) is far more difficult than eq. (1). This may be the reason that methods based on eq. (2) have not been considered in literature until quite recently. ${ }^{8.9}$ An additional problem is that $G_{2}$ and $q$ both are measured with error. This means that the nonlinear regression approach, where $q$ is treated as if it were measured without error, is inadequate and may result in strongly biased values for the reactivity ratios. 8.10

A method for the determination of $r$ values, which takes into account measurement errors in both $G_{2}$ and $q$ and uses the integrated copolymer equation, has been described in literature ${ }^{8}$ and is reported to result in reliable $r$ values. ${ }^{7,11}$ Although the results are not very sensitive to the error structure of the observations," some information on it is necessary for the method to be applicable. In this article we

\footnotetext{
- To whom all correspondence should be addressed.
} 
will describe and solve two numerical problems that may occur when applying the above method: the problem of the dangerous region and the problem of the forbidden region.

\section{THE DANGEROUS REGION}

As can easily be seen, eq. (2) is numerically unstable in the neighborhood of $r_{1}$ $=1$ or $r_{2}=1$. On a computer, intermediate values of $r_{1}$ that are too close to 1 will give rise to abortion of the execution of a program that uses eq. (2) because of exponential overflow. To avoid unnecessary abortion, eq. (2) is replaced by an approximation. By taking the limit $r_{1} \rightarrow 1$, it can be seen that eq. (2) transforms to:

$$
G_{2}=\left(q / q_{0}\right)^{-1-x_{2}} \exp \left[x_{2}\left(q_{0}-q\right)\right]
$$

Likewise, the derivative of $G_{2}$ with respect to $r_{1}$ converges to:

$$
\frac{\partial G_{2}}{\partial r_{1}}=G_{2} x_{2}\left(q_{0}-q\right)\left[1+x_{2}+x_{2}\left(q_{0}+q\right) / 2\right]
$$

where $G_{2}$ is given by eq. (3) of course, instead of by eq. (2). As soon as $r_{1}$ gets too close to 1 one should use eqs. (3) and (4) instead of eq. (2) and its derivative. To determine what is meant by "too close" we first rewrite eq. (2):

$$
G_{2}=\left(\frac{q_{0}\left(q-x_{1} / x_{2}\right)}{q\left(q_{0}-x_{1} / x_{2}\right)}\right)^{1+x_{2}}\left(\frac{1-q x_{2} / x_{1}}{1-q_{0} x_{2} / x_{1}}\right)^{x_{1}}
$$

The first factor converges to $\left(q_{0} / q\right)^{1+x_{2}}$ for $r_{1} \rightarrow 1$. With respect to the second factor we have that (ref. 12 , eq. 4.2.36)

$$
\exp \left(-q x_{2}\right)>\left(1-q x_{2} / x_{1}\right)^{x_{1}}>\exp \left[\left(-q x_{1} x_{2} /\left(x_{1}-q x_{2}\right)\right]\right.
$$

where for simplicity it is assumed that $x_{1}$ and $x_{2}>0$ (if one or both of the $x$ 's are smaller than zero, the results remain essentially the same).

A similar expression with $q_{0}$ instead of $q$ is valid for the denominator of the second factor in eq. (5). From these two inequalities it immediately follows that:

$$
\exp \left(-q x_{2}+\frac{q_{0} x_{1} x_{2}}{x_{1}-q_{0} x_{2}}\right)>\left(\frac{1-q x_{2} / x_{1}}{1-q_{0} x_{2} / x_{1}}\right)^{x 1}>\exp \left(q_{0} x_{2}-\frac{q x_{1} x_{2}}{x_{1}-q x_{2}}\right)
$$

Approximations (3) and (4) may be used if the lower and upper bounds of this inequality are almost equal, i.e.,

$$
\exp \left[x_{2}\left(q+q_{0}-\frac{q x_{1}}{x_{1}-q x_{2}}-\frac{q_{0} x_{1}}{x_{1}-q_{0} x_{2}}\right)\right]<1+\epsilon
$$

with $\epsilon$ small. For large $x_{1}$ this is approximately equivalent to

$$
x_{1}>x_{2}^{3}\left(q z+q^{2}\right) / \epsilon
$$

If $r_{1}<1$ then $x_{1}$ should be replaced by $\left|x_{1}\right|$. The case that $r_{2} \rightarrow 1$ is very similar. Equation (2) transforms to 


$$
G_{2}=\left(\frac{q}{q_{0}}\right)^{x 1} \exp \left[x_{1}\left(\frac{1}{q_{0}}-\frac{1}{q}\right)\right]
$$

The derivative with respect to $r_{2}$ converges to

$$
\frac{\partial G_{2}}{\partial r_{2}}=G_{2} x_{1}\left(\frac{1}{q_{0}}-\frac{1}{q}\right)\left[1+x_{1}+x_{1}\left(\frac{1}{q_{0}}+\frac{1}{q}\right) / 2\right]
$$

Equations (7) and (8) may be used as a sufficiently accurate approximation to eq. (2) and its derivative when

$$
x_{2}>x_{1}^{2}\left(1 / q^{2}+1 / q^{2}\right) / \epsilon
$$

If $r_{2}<1$ then $x_{2}$ should be replaced by $\left|x_{2}\right|$.

Note: If $r_{1} \approx 1$ and $r_{2} \approx 1$ neither eq. (3) nor eq. (7) is applicable. Rarely it may happen that an iterative process winds up with intermediate values of $r_{1}$ and $r_{2}$ that are almost equal to 1 . One should then use some ad hoc method to escape from this doubly dangerous region.

\section{THE FORBIDDEN REGION}

Equation (2) is no longer of any use when

$$
\left(q-x_{1} / x_{2}\right) /\left(q_{0}-x_{1} / x_{2}\right)<0
$$

The execution on a computer of an estimation program that uses eq. (2) will abort because of the invalid argument error. In the course of an iterative estimation process, however, intermediate values of $q_{0}, q, r_{1}$, and $r_{2}$ that satisfy eq. (10) may occur. These points will be called "forbidden" (see Fig. 1). In order to avoid abortion of the process in that case several ad hoc methods are feasible. The one the authors chose is based upon the fact that estimates result from the minimization of some criterion (least squares, for example). When forbidden points occur during this minimization the criterion is assigned a so-called "penalty value" with the effect that the minimization process turns away from those points.

When both $r_{1}$ and $r_{2}$ are smaller (or larger) than 1, "azeotropic" copolymerization may occur. This means that $q$ remains equal $q_{0}$ regardless of the conversion. This only happens when starting at monomer feed ratio $q_{0}=x_{1} / x_{2}=q_{A}$ (see Fig. 1). Equation (10) and thus eq. (2) now become undefined. Azeotropic copolymerization, however, gives exact information about the linear combination of $r_{1}$ and $r_{2}$, that is given by $q_{A}=x_{1} / x_{2}$ and no information about any other linear combination. So, if one happens to stumble upon azeotropic copolymerization, one may use this experiment to determine that particular linear combination, substitute it into the integrated equation, and determine the other linear combinations from the nonazeotropic experiments to estimate $x_{1}$ and $x_{2}$.

For experiments with starting monomer feed ratios in the vicinity of $q_{A}$, the values of $q_{0}, q$, and $x_{1} / x_{2}$ become almost equal and so a considerable number of forbidden points may occur, especially when the measurement error in $q$ is not negligible compared with the drift in $q$. Routine penalty-value assignment may then have an unpredictable effect on the estimation process. A way to handle almost azeotropic copolymerizations is to screen the measurements and to remove outliers. 


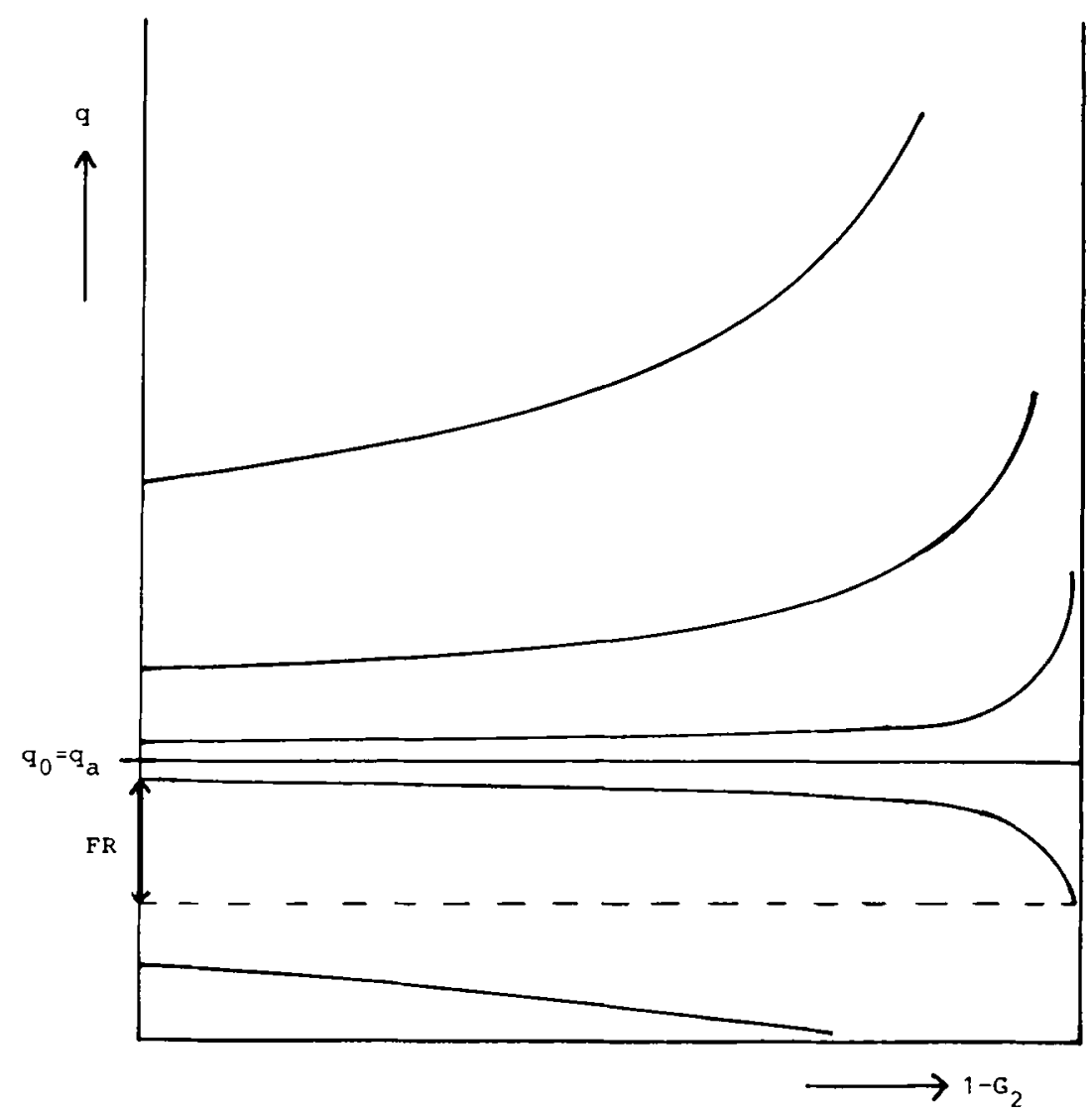

Fig. 1. Momentary monomer feed ratio versus conversion of monomer $2\left(1-G_{2}\right)$. Values of $r_{1}$ and $r_{2}$, such that $\left(r_{2}-1\right) /\left(r_{1}-1\right)$ is contained in FR, are forbidden.

\section{CONCLUSION}

By solving the numerical problems discussed in this article the integrated copolymer equation considerably gains in usefulness and applicability. Using the integrated equation allows for higher conversions to be taken into account and consequently results in more precise and accurate estimates for the reactivity ratios. ${ }^{7,11}$

\section{References}

1. T. Alfrey Jr. and G. Goldfinger, J. Chem. Phys., 12, 205 (1944).

2. F. R. Mayo and F. M. Lewis, J. Am. Chem. Soc., 66, 1594 (1944).

3. M. Fineman and S. D. Ross, J. Polym. Sci, 5, 259 (1950).

4. F. Tüdös, T. Kelen, T. Földes-Berezsnich, and B. Turcsanyi, J. Macromol. Sci. Chem, 10(8), $1513(1976)$.

5. T. Kelen, F. Tüdös, and B. Turcsanyi, Polym. Bull. 2, 71 (1980).

6. D. G. Watts, H. N. Linssen, and J. Schrijver, J. Polym. Sci. Polym. Chem. Ed., 18, 1285 (1980).

7. F. Hautus, H. N. Linssen, and A. German, J. Polym. Sci. Polym. Chem. Ed., 22, 3487 (1984).

8. R. Van der Meer, H. N. Linssen, and A. L. German, J. Polym. Sci. Polym. Chem. Ed., 16, 2915 (1978). 
9. B. Yamada, M. Itahashi, and T. Otsu, J. Polym. Sci. Polym. Chem. Ed., 16, 1719 (1978).

10. H. Patino-Leal, P. M. Reilly, and H. F. O'Driscoll, J. Polym. Sci. Polym. Lett. Ed., 18, 219 (1980).

11. F. Hautus, H. N. Linssen, and A. L. German, J. Polym. Sci Polym. Chem. Ed., 22, 3661 (1984).

12. M. Abramowitz and J. A. Stegeen, Eds., Handbook of mathematical functions, Dover, New York, 1964.

Received October 3, 1984

Accepted December 6, 1984 